\title{
Retraction Note: Pathological dislocation of the hip due to coxotuberculosis in children: a 29-case report
}

\author{
Xin Jiang, Yuan Li', Lijun Liu, MingXin Peng, XueYang Tang, DaoXi Wang and XiaoDong Yang
}

\section{Retraction}

The Publisher and Editor regretfully retract this article [1] because the peer-review process was inappropriately influenced and compromised. As a result, the scientific integrity of the article cannot be guaranteed. A systematic and detailed investigation suggests that a third party was involved in supplying fabricated details of potential peer reviewers for a large number of manuscripts submitted to different journals. In accordance with recommendations from COPE we have retracted all affected published articles, including this one. It was not possible to determine beyond doubt that the authors of this particular article were aware of any third party attempts to manipulate peer review of their manuscript.

Received: 4 March 2015 Accepted: 4 March 2015

Published online: 26 March 2015

\section{References}

1. Jiang $X, L i Y$, Liu L, Peng MX, Tang XY, Wang DX, et al. Pathological

dislocation of the hip due to coxotuberculosis in children: a 29-case report. J Orthop Surg Res. 2014;9:16.

* Correspondence: yuanlilili@hotmail.com

Department of Pediatric Surgery, West China Hospital, Sichuan University, No.

37 Guoxue Road, Chengdu, Sichuan 610041, People's Republic of China

Submit your next manuscript to BioMed Central and take full advantage of:

- Convenient online submission

- Thorough peer review

- No space constraints or color figure charges

- Immediate publication on acceptance

- Inclusion in PubMed, CAS, Scopus and Google Scholar

- Research which is freely available for redistribution 